\title{
Model parameters of four important vegetable crops for improved water use and yield estimation
}

\author{
JT Vahrmeijer ${ }^{1,3 *}$, JG Annandale', JM Steyn' and KL Bristow ${ }^{1,2,4}$ \\ 'Department of Plant and Soil Sciences, University of Pretoria, Private Bag X20, Hatfield, Pretoria 0028, South Africa \\ ${ }^{2}$ University of Pretoria Water Institute, University of Pretoria, Private Bag X20, Hatfield, Pretoria 0028, South Africa \\ ${ }^{3}$ Citrus Research International, PO Box 28, Nelspruit 1200, South Africa \\ ${ }^{4}$ CSIRO Agriculture and Food, PMB Aitkenvale, Townsville, QLD 4814, Australia
}

\begin{abstract}
High-value vegetable crops are typically grown under irrigation to reduce production risk. For water resource planning it is essential to be able to accurately estimate water use of irrigated crops under a wide range of climatic conditions. Crop water use models provide a means to make water use and yield estimates, but need crop- and even cultivar-specific parameters. There is generally a lack of crop-specific model parameters for some important commercially grown vegetable crops, especially parameters determined over both summer and winter seasons. The experimental site used in this study was on the Steenkoppies Aquifer, a catchment under stress and an important vegetable production area in South Africa. Crop-specific growth parameters and water use for 4 selected high-value vegetable crops (beetroot, cabbage, carrots and broccoli) were measured over multiple seasons (two summers and one winter). These were used to parameterise the Soil Water Balance (SWB) generic crop growth model for both summer and winter seasons. In seasons where the same cultivar was planted, a single set of model parameters could be used to successfully simulate crop growth and water use. Results show that the amount of irrigation water required is dependent on season and rainfall, with broccoli having the lowest $\left(1.8-2.7 \mathrm{~kg} \mathrm{~m}^{-3}\right)$ and beetroot the highest $\left(12.2-23.4 \mathrm{~kg} \mathrm{~m}^{-3}\right)$ water productivity $\left(W P_{F M}\right)$, defined as fresh mass of marketable product per unit water consumed. The root crops had a greater harvest index $\left(H I_{D M}\right)$ than cabbage and broccoli. The parameters obtained expand the current database of SWB crop growth parameters for vegetables and can be used in a wide range of mechanistic simulation models to improve water management at field and catchment levels.
\end{abstract}

Keywords: SWB model, Steenkoppies Aquifer, carrot, broccoli, beetroot, cabbage

\section{INTRODUCTION}

Implementing crop models for analysing the processes linking weather and soil conditions to crop growth and water use are valuable aids for planning and for making management decisions at different spatial scales (field or catchment), time periods (short and long term) and for different climatic conditions (average and extreme). Such models also provide information on resource dynamics and have the capability of predicting future events for different scenarios (Singels et al., 2010). Jones (2013) distinguishes between descriptive (more empirical) and explanatory (more quantitative) models. Boote et al. (2010) groups potential uses of crop models into 5 primary categories: (i) synthesis of research knowledge, (ii) crop system decision management, (iii) policy analysis, (iv) real-time decision support and (v) education purposes. Different aspects of the soil-plant-atmosphere continuum are emphasized with different modelling approaches and with ultimate model objective. For example, Ranatunga et al. (2008) reviewed models with the emphasis on soil water, while Jones (2013) considered modelling of plant water relations and irrigation of horticultural crops. Steduto et al. (2009) explains the concepts and principles of modelling biomass production and yield, whilst Stöckle et al. (2014) described simulation models for multi-crop, multi-year cropping systems.

The history of the development of models for crop growth and crop water relations in South Africa was reviewed by Singels et al. (2010) and approaches for irrigation scheduling

To whom all correspondence should be addressed.

+27 11396 2233; fax: +27 12420 4120;

e-mail: jtv@villacrop.co.za

Received 17 November 2016; accepted in revised form 20 August 2018 by Annandale et al. (2011). A mechanistic crop growth model, called the Soil Water Balance (SWB) model, was developed in South Africa and is well-established and widely used (Annandale et al., 1999; Jovanovic and Annandale, 1999; Jovanovic et al., 1999; Jovanovic and Annandale, 2000; Jovanovic et al., 2000; du Sautoy et al., 2003; Annandale et al., 2004; Beletse et al., 2008; Singels et al., 2010; Fessehazion et al., 2014; Tesfamariam et al., 2015). SWB was developed as a real-time, generic crop growth, soil water balance, irrigation scheduling model (Annandale et al., 1999; Annandale et al., 2011). For SWB and indeed other mechanistic models to simulate crop growth and water use, crop-specific model parameters are required. SWB predicts the water balance and crop growth from weather, soil and crop data. PennmanMonteith grass reference daily evapotranspiration (ETo) in $\mathrm{mm}$ (Pereira et al., 2015) is calculated from weather data, and thermal time is used to describe crop development. Soil water movement is simulated using a layered cascading model, where each layer can have its own physical properties. Rainfall interception, drainage and runoff are also accounted for in the model. Dry mass production is calculated after crop emergence and until maturity on a daily basis as either transpirationor radiation-limited (Goudriaan and Van Laar, 2012), and assimilates are partitioned to different plant organs depending on phenological stage and water stress level.

Vegetables are seen as high-value crops, ranking amongst the top 5 agricultural commodities in monetary terms worldwide (FAO, 2017). In South Africa, vegetables collectively rank $7^{\text {th }}$ in importance for crops produced under irrigation (Backeberg et al., 1996). Vegetables represent a wide range of crops that differ greatly in growth pattern, plant structure and even cultivation methods and generally require irrigation for 
optimum yield. A better understanding of crop water use is needed to optimise irrigation water management at field level for irrigation system design, to effect water and energy savings, for salt management (Jovanovic et al., 1999; Beletse et al., 2008) and to facilitate water management at catchment level, for example, water allocations during periods of low rainfall. However, there is a lack of information on crop-specific parameters for vegetables in general (Jovanovic et al., 1999). This is particularly true for commercially grown vegetables in both warm and cool seasons. Therefore, the objectives of this study were to measure, over multiple seasons, seasonal growth and water use of selected important vegetable crops commercially grown on the Highveld (approximate altitude $1700 \mathrm{~m}$ with temperate climate), and to establish crop-specific growth parameters for summer and winter cropping to be used in mechanistic simulation growth models. Such growth models can then be used to estimate, for example, water abstraction from groundwater resources for the allocation and management of water use at farm or catchment level. This is urgently required in the case of the Steenkoppies Aquifer, and no doubt in many other catchments under stress, where careful management of water resources is required.

This study formed part of a larger study (Reinders et al., 2010), to determine irrigation water use efficiency. Field trials that reflect the crops, cultivars and local practices were conducted on the Steenkoppies Aquifer. The study was conducted over 3 seasons to fall within the time constraints of the larger study.

\section{MATERIAL AND METHODS}

\section{Experimental set-up}

Field trials were carried out at Rosaly Boerdery $\left(26^{\circ} 04^{\prime} \mathrm{S}\right.$ and $27^{\circ} 36^{\prime}$ E, $1678 \mathrm{~m}$ amsl), a Global GAP-audited (good agricultural practices) farming enterprise on the Steenkoppies Aquifer in Tarlton, Gauteng, South Africa. The experiment was conducted on one half of a 24 ha centre pivot, which was divided into five adjacent 2 ha experimental fields. The area not used for the trial was planted with vegetables for commercial production. Soil preparation reflected local practices and involved ploughing, rotovating and the forming of $1.2 \mathrm{~m}$ wide raised beds with 3 rows of vegetables planted on each raised bed. Four vegetable species, which are commonly grown on the Steenkoppies Aquifer, were monitored over two summer (October to March) and one winter (April to September) season. 'Tenacity' which is a warm season, round head cabbage hybrid was planted in summer and 'Grandslam' a medium maturing winter hybrid with a round head that flattens at the base at full maturity, in the winter season. Both cultivars belong to the white cabbage group (Brassica oleracea L. var. capitata), are large framed with a semi-erect growth pattern and are commonly grown for the fresh market. In summer, an early-maturing Nantes carrot (Daucus carota L.) hybrid cultivar ('Star 3006') with medium to long leaves that grow upright was planted, and in winter, a medium to early Nantes hybrid cultivar ('Dordogne') with vigorous long leaves was grown. The same beetroot cultivar (Beta vulgaris 'Red Ace'), was planted in both the summer and winter trials. Two broccoli cultivars belonging to different groups were planted, 'Star 2204' (Brassica oleracea L. var. italica) in summer and 'Parthenon' (Brassica oleracea L. var. cymosa) in winter.

The cultivars, planting and harvest dates, plant densities and growth periods are summarised in Table 1. Apparent inconsistencies between crops in their growth periods in days and day degrees, are due to differences in their base temperatures. The between-row spacing for the different vegetable crops was $0.4 \mathrm{~m}$. In-row spacing of the cabbage seedlings was $0.44 \mathrm{~m}$ and $0.35 \mathrm{~m}$ for the broccoli seedlings, for both the summer and winter seasons. Trial plots (4 replicates of $30 \mathrm{~m}^{2}$ per crop) were randomly chosen and clearly marked within the experimental fields. Soil samples were taken and analysed to determine fertiliser requirements. Each experimental field was fertilised and managed according to its specific needs. Pre- and post-emergence herbicides were applied for weed control. Spraying for pests occurred only when required.

Climatic data, both historical and for the period of these trials, was obtained from an automatic weather station at Deodar $\left(26^{\circ} 08^{\prime} \mathrm{S}, 27^{\circ} 35^{\prime} \mathrm{E}, 1700 \mathrm{~m}\right.$ altitude) that is owned and maintained by the local Department of Agriculture, $7.5 \mathrm{~km}$ from the study site. A summary of climatic data for the experimental periods is presented in Table 2. For the 2008 summer season (2008/09/16-2008/12/22) the experimental period had a higher average vapour pressure deficit $(V P D)$ than for the 2008 winter and previous summer experimental periods. As expected, the average radiation and temperatures

\begin{tabular}{|c|c|c|c|c|c|c|c|}
\hline \multicolumn{8}{|c|}{$\begin{array}{c}\text { TABLE } 1 \\
\text { Crops, planting and harvest dates, plant densities and growth periods of the field trials }\end{array}$} \\
\hline \multirow{2}{*}{ Season } & \multirow{2}{*}{ Crop } & \multirow{2}{*}{ Cultivar } & \multirow{2}{*}{ Plant date } & \multirow{2}{*}{ Harvest date } & \multirow{2}{*}{$\begin{array}{l}\text { Plant density } \\
\text { (plants } \cdot \mathrm{m}^{-2} \text { ) }\end{array}$} & \multicolumn{2}{|c|}{ Growth period } \\
\hline & & & & & & (days) & $\left(d^{\circ} \mathrm{C}\right)$ \\
\hline \multirow{4}{*}{$\begin{array}{l}\text { Summer } \\
2007 / 08\end{array}$} & Cabbage & Tenacity & $2007 / 12 / 13$ & $2008 / 03 / 26$ & 3.9 & 104 & 1613 \\
\hline & Broccoli & Star 2204 & $2007 / 12 / 13$ & $2008 / 03 / 16$ & 4.9 & 94 & 1899 \\
\hline & Beetroot & Red Ace & $2007 / 12 / 18$ & $2008 / 03 / 12$ & 57.7 & 85 & 1355 \\
\hline & Carrots & Star 3006 & $2007 / 12 / 18$ & $2008 / 03 / 26$ & 62.8 & 99 & 1238 \\
\hline \multirow{4}{*}{$\begin{array}{l}\text { Winter } \\
2008\end{array}$} & Cabbage & Grandslam & $2008 / 04 / 29$ & $2008 / 09 / 09$ & 3.9 & 133 & 1445 \\
\hline & Broccoli & Parthenon & $2008 / 04 / 29$ & $2008 / 08 / 14$ & 4.9 & 107 & 1288 \\
\hline & Beetroot & Red Ace & $2008 / 04 / 29$ & $2008 / 09 / 29$ & 57.7 & 153 & 1356 \\
\hline & Carrots & Dordogne & $2008 / 04 / 29$ & $2008 / 09 / 23$ & 62.8 & 147 & 1286 \\
\hline \multirow{3}{*}{$\begin{array}{l}\text { Summer } \\
2008\end{array}$} & Cabbage & Tenacity & $2008 / 09 / 16$ & $2008 / 12 / 18$ & 3.9 & 93 & 1477 \\
\hline & Beetroot & Red Ace & $2008 / 09 / 16$ & $2008 / 12 / 11$ & 57.7 & 86 & 1359 \\
\hline & Carrots & Star 3006 & $2008 / 09 / 16$ & $2008 / 12 / 22$ & 75.0 & 97 & 1281 \\
\hline
\end{tabular}


were lower for the 2008 winter experimental period, than for the two summer periods (Table 2).

A profile pit was dug at the experimental site and soil samples were taken at $0.15 \mathrm{~m}$ intervals to a depth of $0.6 \mathrm{~m}$ to determine bulk density $\left(\rho_{b}\right)$, soil texture and volumetric soil water content ( 9 ) at field capacity $(F C)$ and permanent wilting point $(P W P)$. The $\rho_{b}$ of the soils was determined by gently tapping a cylinder of known volume horizontally into the side of the profile pit. The soil was removed and dried at $105^{\circ} \mathrm{C}$ for $24 \mathrm{~h}$. Volumetric water content at $F C$ was determined, before planting, by saturating a portion of the field which was then left for $48 \mathrm{~h}$ to drain before sampling, while $P W P$ was determined at the end of the season by withholding irrigation on a section of the experimental plot until the plants died. Soil samples of a known volume were taken and $\vartheta$ was calculated from the mass loss before and after the soil samples were dried at $105^{\circ} \mathrm{C}$ for $24 \mathrm{~h}$. Bulk density varied from $1.42-1.54 \mathrm{Mg} \cdot \mathrm{m}^{-3}$ for the $0-60 \mathrm{~cm}$ soil profile (Table 3 ). Clay content varied from 9.8-13.3\%, $\theta$ at $F C$ from $0.147-0.215 \mathrm{~m}^{3} \cdot \mathrm{m}^{-3}$ and $P W P$ from $0.067-0.088 \mathrm{~m}^{3} \cdot \mathrm{m}^{-3}$ (Table 3). The soils of the experimental site have a textural class of a loamy sand and are classified as a Bainsvlei soil form (Soil Classification Working Group, 1991).

\section{Field measurements}

Volumetric soil-water content (9) was measured at least once a week with a calibrated neutron water meter. Readings were taken in the middle of each trial plot at 3 positions, one within a plant row and on either side of the plant row at $0.15 \mathrm{~m}$ depth increments down to $0.6 \mathrm{~m}$. The soil-water deficit to field capacity was calculated for each layer and the average for the three different positions determined. Rain gauges were installed to measure irrigation $(I)$ and precipitation $(P)$. Infiltration rate was measured according to the method described by Reinders and Louw (1984) and ranged between $17 \mathrm{~mm} \cdot \mathrm{h}^{-1}$ and $36 \mathrm{~mm} \cdot \mathrm{h}^{-1}$ on a $30 \mathrm{~min}$ test run. Due to the high infiltrability and flat topography of the field, runoff $(R)$ was assumed to be negligible.

Plant material for growth analyses was harvested from four $1 \mathrm{~m}^{2}$ plots at least once every fortnight and divided into leaves, stems, roots and harvestable components (underground storage organs for carrots and beetroot, and edible vegetative and reproductive portions of cabbage and broccoli). Leaf area index $(L A I)$ was calculated from photosynthetically active leaf area measured with a belt-driven leaf area meter (LiCor, Lincoln, Nebraska, USA). For cabbage and broccoli, the outer green leaves were taken as photosynthetically active. Total and harvestable fresh mass was determined directly after harvest, whereafter the plant material was dried in an oven at $60^{\circ} \mathrm{C}$ until constant mass to determine dry mass of the different plant components. Fractional interception (FI) of photosynthetically active radiation (PAR, $400-700 \mathrm{~nm}$ ) was determined periodically throughout the season. For field measurements, 10 pairs of readings for each vegetable crop, one above and one below the crop canopy, were taken in rapid succession with a sunfleck ceptometer (Decagon, Pullman, USA) to estimate canopy cover.

\section{Modelling parameters}

Seasonal evapotranspiration $(E T)$ was calculated using the soil water balance equation:

$$
E T=I+P-R-D-\Delta S
$$

where $I$ is irrigation, $P$ is precipitation, $R$ is runoff, $D$ is drainage and $\Delta S$ is the change in soil-water-storage for the $0.6 \mathrm{~m}$ soil profile. Drainage was estimated with the SWB model once parameterised for crop growth, and $\Delta \mathrm{S}$ was calculated from soil water content measurements at the beginning and end of the season.

The SWB model uses a mechanistic approach to model crop growth and requires, among others, the following parameters for each crop:

i) Canopy extinction coefficient $\left(K_{s}\right)$ for total solar radiation

ii) Dry matter: Transpiration ratio, adjusted for vapour pressure deficit $\left(D W R, \mathrm{~kg} \cdot \mathrm{kg}^{-1} \cdot \mathrm{Pa}\right)$

iii) Radiation-use efficiency (RUE, $\mathrm{kg} \cdot \mathrm{MJ}^{-1}$ )

iv) Leaf-stem dry matter partitioning $\left(p, \mathrm{~m}^{2} \cdot \mathrm{kg}^{-1}\right)$

v) Specific leaf area $\left(S L A, \mathrm{~m}^{2} \cdot \mathrm{kg}^{-1}\right)$

\begin{tabular}{|c|c|c|c|c|c|c|}
\hline \multicolumn{7}{|c|}{$\begin{array}{l}\text { TABLE } 2 \\
\text { Mean daily VPD (vapour pressure deficit), radiation and temperatures measured for the experimental periods }\end{array}$} \\
\hline \multirow{2}{*}{ Season } & \multirow{2}{*}{ Growth period } & \multirow{2}{*}{$\begin{array}{l}\text { VPD } \\
(\mathrm{kPa})\end{array}$} & \multirow{2}{*}{$\begin{array}{l}\text { Radiation } \\
\left(\mathrm{MJ} \cdot \mathrm{m}^{-2} \cdot \mathrm{d}^{-1}\right)\end{array}$} & \multicolumn{3}{|c|}{ Temperatures $\left({ }^{\circ} \mathrm{C}\right)$} \\
\hline & & & & Average & Min & Max \\
\hline Summer & $2007 / 12 / 13-2008 / 03 / 26$ & 0.65 & 20.4 & 19.8 & 14.2 & 25.4 \\
\hline Winter & 2008/04/29-2008/09/29 & 0.68 & 15.1 & 13.2 & 5.2 & 21.2 \\
\hline Summer & $2008 / 09 / 16-2008 / 12 / 22$ & 1.0 & 21.9 & 20.3 & 13.2 & 27.3 \\
\hline
\end{tabular}

\begin{tabular}{|l|c|c|c|c|c|c|}
\hline \multicolumn{7}{|c|}{ TABLE 3 } \\
\hline \multirow{2}{*}{ Depth $(\mathbf{c m})$} & $\rho_{\mathrm{b}}\left(\mathbf{M g} \cdot \mathrm{m}^{-3}\right)$ & \multicolumn{2}{|c|}{ Volumetric water content $\left(\mathbf{m}^{3} \cdot \mathbf{m}^{-3}\right)$} & \multicolumn{3}{|c|}{ Particle size distribution (\%) } \\
\cline { 3 - 7 } & & FC & PWP & Sand & Clay & Silt \\
\hline 15 & 1.42 & 0.147 & 0.067 & 79.1 & 12.6 & 8.3 \\
\hline 30 & 1.54 & 0.151 & 0.082 & 82.2 & 9.8 & 8.0 \\
\hline 45 & 1.54 & 0.187 & 0.088 & 82.0 & 10.4 & 7.6 \\
\hline 60 & 1.46 & 0.215 & 0.086 & 77.8 & 13.3 & 8.9 \\
\hline Average & 1.49 & 0.173 & 0.081 & 80.3 & 11.5 & 8.2 \\
\hline
\end{tabular}

$\rho_{b}:$ Bulk density, FC: Field capacity, PWP: Permanent wilting point 
vi) Growing day degrees $\left(G D D, \mathrm{~d}^{\circ} \mathrm{C}\right)$ required to reach different development stages

vii) Maximum root depth $\left(R D_{\max }, \mathrm{m}\right)$

The canopy extinction coefficient $\left(K_{P A R}\right)$, measured with a ceptometer, is for photosynthetically active radiation (PAR) and is used in some models to calculate photosynthesis as a function of intercepted PAR. $K_{P A R}$ is a crop-specific parameter where the fraction of PAR intercepted $\left(F I_{P A R}\right)$ is well correlated with LAI (Goudriaan and Van Laar, 2012) and canopy architecture (Campbell and Norman, 1998). $K_{P A R}$ is calculated from the exponential relationship between field measurements of $F I_{P A R}$ and LAI (Campbell and Van Evert, 1994):

$$
F I_{P A R}=1-\mathrm{e}^{-L A I K_{P A R}}
$$

However, the canopy extinction coefficient for total solar radiation $\left(K_{s}\right)$ is used in SWB to determine radiation-limited dry matter production (Goudriaan and Van Laar, 2012) and for partitioning of $E T$ into evaporation and crop transpiration (Ritchie, 1972). Therefore, measured $K_{P A R}$ was converted to $K_{s}$ according to the procedure recommended by Campbell and Van Evert (1994) as described by Jovanovic et al. (1999).

Water vapour and carbon dioxide $\left(\mathrm{CO}_{2}\right)$ both diffuse through the stomata of leaves and, therefore, the assimilation of carbon is accompanied by transpirational water loss that can be described by a simple gas exchange dry matter production model (Campbell and Norman, 1998):

$$
D M=D W R \frac{T r}{V P D}
$$

where $D M$ is total dry matter $\left(\mathrm{kg} \mathrm{m}^{-2}\right)$, which includes all above-ground canopy dry mass $(C D M)$ and, in the case of root crops, the underground harvestable storage organ. $T r$ is transpiration $(\mathrm{mm}), V P D$ is the vapour pressure deficit $(\mathrm{Pa})$ and the slope of the relation between $D M$ and water use, $D W R$ (dry matter water ratio), is the water productivity (Van Halsema and Vincent, 2012) of the harvestable dry matter $\left(W P_{D M}\right)$ per unit of water consumed (ET) adjusted for VPD. Due to the difficulties in determining transpiration and total dry matter, ET (not Tr) and above-ground and harvestable root mass (not total $D M$ ) were used to estimate a lower limit value of $D W R$.

Dry matter production, under conditions of radiationlimited growth, is modelled as a function of the daily cumulative product of fractional interception $\left(F I_{R A D}\right)$ and incoming solar radiation $\left(R_{s}\right)$, after Goudriaan and Van Laar (2012):

$$
D M=R U E \sum_{i=1}^{n} F I_{R A D} R_{S}
$$

$R U E$ is the slope of the regression between intercepted solar radiation and $D M$ production, forced through the origin. Daily increments in $D M$ are calculated either as transpiration-limited (Eq. 3) or radiation-limited (Eq. 4). Dry matter is preferentially partitioned to reproductive sinks and roots, and remaining $D M$ is partitioned to leaves and stems $(C D M)$. Specific leaf area $(S L A)$, calculated as the ratio between leaf area and leaf dry matter, is taken as the seasonal average for each crop, but caution should be taken with the use of this parameter because SLA tends to decrease during the season (Jovanovic et al., 1999). The leaf-stem dry matter partitioning $(p)$ is a function of $S L A, L A I$ and CDM and the lower the value of $p$, the greater the apportionment of biomass to leaves.

$$
\frac{C D M S L A}{L A I}-1=p C D M
$$

Growing day degrees $(G D D)$ was determined from daily average air temperature after Campbell and Norman (1998):

$$
G D D=\sum_{i=1}^{n}\left(\frac{T_{x i}+T_{n i}}{2}-T_{b}\right) \Delta t
$$

where the unit for $G D D$ is $\mathrm{d}^{\circ} \mathrm{C}, \mathrm{T}_{x}$ is the daily maximum and $T_{n}$ the daily minimum air temperature $\left({ }^{\circ} \mathrm{C}\right)$ and $i$ the daily increment until $n$ days, the end of a development stage. $T_{b}$ is the base temperature and if the daily average temperature is less than $T_{b}$ then zero is added to the sum for that day. The time step $\Delta t$ is 1 day. The maximum root depth was taken as $0.6 \mathrm{~m}$ for all the vegetable crops. A detailed description of the SWB model and how the different parameters are determined is given by Annandale et al. (1999) and Jovanovic et al. (1999).

\section{RESULTS AND DISCUSSION}

Although growth period of a specific cultivar in thermal time $\left(\mathrm{d}^{\circ} \mathrm{C}\right)$ is constant regardless of season, as expected, growth period in calendar days was extended quite dramatically during winter. For example, beetroot grew approximately 68 days longer in winter than during the summer seasons (Table 1) due to lower temperatures (Table 2).

Large differences in thermal time requirements between cultivars of a specific crop can be attributed to genetic differences. This is clearly illustrated for broccoli (Table 1), and supported by Tan et al. (2000), who found large differences in thermal time requirement for emergence to floral initiation between broccoli cultivars. In addition, the somewhat arbitrary harvest date of vegetable crops makes it difficult to report thermal time to harvest.

Information on $I, P, \Delta S, D, E T, D M$, harvestable dry matter $(H D M)$, water productivity $\left(W P_{F M}\right)$ based on fresh mass and harvest index $\left(H I_{D M}\right)$ on a dry mass basis of the studied crops is given in Table 4. $D$ is the cumulative drainage estimated with SWB and $\Delta S$ was taken as the difference between the soil water content at the end and beginning of the trial. It was assumed that no runoff occurred, because the field at the experimental site was laser planed, soils are sandy with a low clay content (Table 3) and the measured infiltrability exceeded $17 \mathrm{~mm} \cdot \mathrm{h}^{-1}$, and mechanical cultivation was used to reduce weeds and crust formation. ET for the growth period was calculated from the soil water balance equation (Eq. 1) and was higher during the winter season than the summer seasons due to longer growing periods (Table 4). Dry matter production (DM) includes all above-ground canopy dry mass $(C D M)$ and in the case of root crops the underground harvestable storage organ. Yield $(Y)$ refers to the fresh marketable portion of the relevant vegetable crop and when dried to constant mass is termed harvestable dry matter $(H D M)$. According to Van Halsema and Vincent (2012) WP $P_{F M}$ for vegetables and fruit crops is defined as the fresh mass of marketable product $(Y)$ per unit of water consumed $(E T)$. Substantially higher rainfall with less irrigation was recorded for the 2007/08 summer than for the 2008 winter and 2008 summer seasons. More irrigation water was applied to the vegetables during the winter months than during the summer months (Table 4 ) because of longer growth periods (Table 1) and lower rainfall to supplement irrigation. Carrot yield was below average during the 2007/08 summer due to the outbreak of Alternaria, a foliar disease, 
and spraying with appropriate chemicals to control the disease could not commence in time because frequent rain hindered access to the field. Therefore, results from this field were not used in the development of growth parameters and testing of the SWB model. Beetroot had the highest $D M, H D M$, and $Y$ for all three seasons, and therefore also had the highest $W P_{F M}$ that ranged from $12.2-23.4 \mathrm{~kg} \cdot \mathrm{m}^{-3}$. Broccoli, with its flower head as marketable product, on the other hand, had the lowest $D M, H D M, Y$ and $W P_{F M}$ (Table 4). The $W P_{F M}$ (fresh mass basis) and $H I_{D M}$ (dry mass basis) for the respective vegetable species varied somewhat due to cultivar differences between winter and summer seasons and seasonal changes in rainfall and yield. However, values obtained were generally in line with those calculated from data of Jovanovic et al. (1999), where $W P_{F M}$ of winter grown cabbage was $12 \mathrm{~kg} \cdot \mathrm{m}^{-3}$, beetroot was $13 \mathrm{~kg} \cdot \mathrm{m}^{-3}$, but their carrot crop exhibited a higher winter productivity of $15 \mathrm{~kg} \cdot \mathrm{m}^{-3}$. Harvest Index of Jovanovic et al. (1999) for beetroot (0.54) and carrots (0.71) was of the same order as in the present study, while their cabbage (0.61) $H I_{D M}$ was higher. Broccoli had the lowest $H I_{D M}$ in the 2007/08 summer (0.17) and the 2008 winter (0.13) season, because the marketable portion consists of the florets, which is only a small portion of the total dry matter of the plant (Table 4).

\section{Specific crop growth parameters}

$K_{\text {PAR }}$ determined from crop measurements for broccoli and beetroot and used to parameterise the SWB model is illustrated in Fig. 1. The $K_{P A R}$ values for all the crops and seasons are given in Table 5 .

$K_{P A R}$ for broccoli is 1.14 and for beetroot 0.90 (Fig. 1). $K_{P A R}$ values for carrots, cabbage and beetroot were lower for the winter season than for the two summer seasons, due to seasonal effects (Table 5). For example cabbage winter cultivars with fewer, smaller and more erect leaves that intercept less radiation will have lower $K_{P A R}$ values. $K_{P A R}$ for vegetables with the same cultivars (beetroot and cabbage) were similar, while the two broccoli cultivars had approximately the same $K_{P A R}$ values for the summer and winter season, with $K_{P A R}$ slightly higher for the winter season, indicating similar canopy architecture.

The RUE is sometimes called 'radiation conversion efficiency', but Sinclair and Muchow (1999) argued that the

\begin{tabular}{|c|c|c|c|c|c|c|c|c|c|c|c|}
\hline Season & ta for irr & rai & na & $\begin{array}{l}\text { soil wa } \\
\text { table }\end{array}$ & $\begin{array}{r}\text { TA } \\
\text { conte } \\
\text { s gro }\end{array}$ & raina & $\begin{array}{l}\text { vapotra } \\
\text { seasons }\end{array}$ & iratio & d plant & iass fo & erent \\
\hline Season & Crop & $\begin{array}{c}I \\
(\mathrm{~mm})\end{array}$ & $\begin{array}{c}P \\
(\mathrm{~mm})\end{array}$ & $\begin{array}{c}\Delta S \\
(\mathrm{~mm})\end{array}$ & $\begin{array}{c}D \\
(\mathrm{~mm}) \\
\end{array}$ & $\begin{array}{c}E T \\
(\mathrm{~mm})\end{array}$ & $\begin{array}{c}D M \\
\left(\mathrm{~kg} \cdot \mathrm{m}^{-2}\right)\end{array}$ & $\begin{array}{c}H D M \\
\left(\mathrm{~kg} \cdot \mathrm{m}^{-2}\right)\end{array}$ & $\begin{array}{c}Y \\
\left(\mathrm{Mg} \cdot \mathrm{ha}^{-1}\right)\end{array}$ & $\begin{array}{c}W P_{F M} \\
\left(\mathrm{~kg} \cdot \mathrm{m}^{-3}\right)\end{array}$ & $H I_{D M}$ \\
\hline Summer & Cabbage & 202 & 335 & 24 & 135 & 378 & 0.82 & 0.36 & 56.9 & 15.1 & 0.44 \\
\hline $2007 / 08$ & Broccoli & 190 & 300 & 14 & 145 & 331 & 0.46 & 0.08 & 8.9 & 2.7 & 0.17 \\
\hline & Beetroot & 198 & 240 & 10 & 56 & 372 & 1.19 & 0.96 & 74.2 & 23.4 & 0.64 \\
\hline & Carrots & 198 & 240 & 28 & 58 & 352 & 0.53 & 0.22 & 38.7 & 11.0 & 0.42 \\
\hline Winter & Cabbage & 469 & 76 & 8 & 0 & 537 & 0.87 & 0.30 & 67.8 & 12.6 & 0.35 \\
\hline 2008 & Broccoli & 317 & 54 & 18 & 0 & 353 & 0.61 & 0.08 & 6.4 & 1.8 & 0.13 \\
\hline & Beetroot & 568 & 76 & 14 & 0 & 630 & 2.06 & 1.21 & 76.5 & 12.2 & 0.59 \\
\hline & Carrots & 548 & 76 & -5 & 9 & 620 & 0.80 & 0.66 & 53.9 & 8.7 & 0.83 \\
\hline Summer & Cabbage & 242 & 189 & -3 & 1 & 433 & 0.78 & 0.32 & 49.0 & 11.3 & 0.41 \\
\hline 2008 & Beetroot & 262 & 189 & 6 & 0 & 445 & 1.44 & 1.04 & 88.8 & 23.0 & 0.72 \\
\hline & Carrots & 212 & 189 & 5.1 & 29 & 361 & 0.56 & 0.33 & 58.7 & 16.3 & 0.60 \\
\hline
\end{tabular}

I: Irrigation, P: Precipitation for the growing period, $\Delta$ S: Change in soil water content, D: Drainage, ET: Evapotranspiration, DM: Dry matter, HDM: Harvestable dry matter, Y: Yield (fresh marketable plant parts), $\mathrm{WP}_{\mathrm{FM}}$ : Water Productivity (from $\mathrm{Y}$ and ET), $\mathrm{HI}_{\mathrm{DM}}$ : Harvest Index calculated on dry mass basis
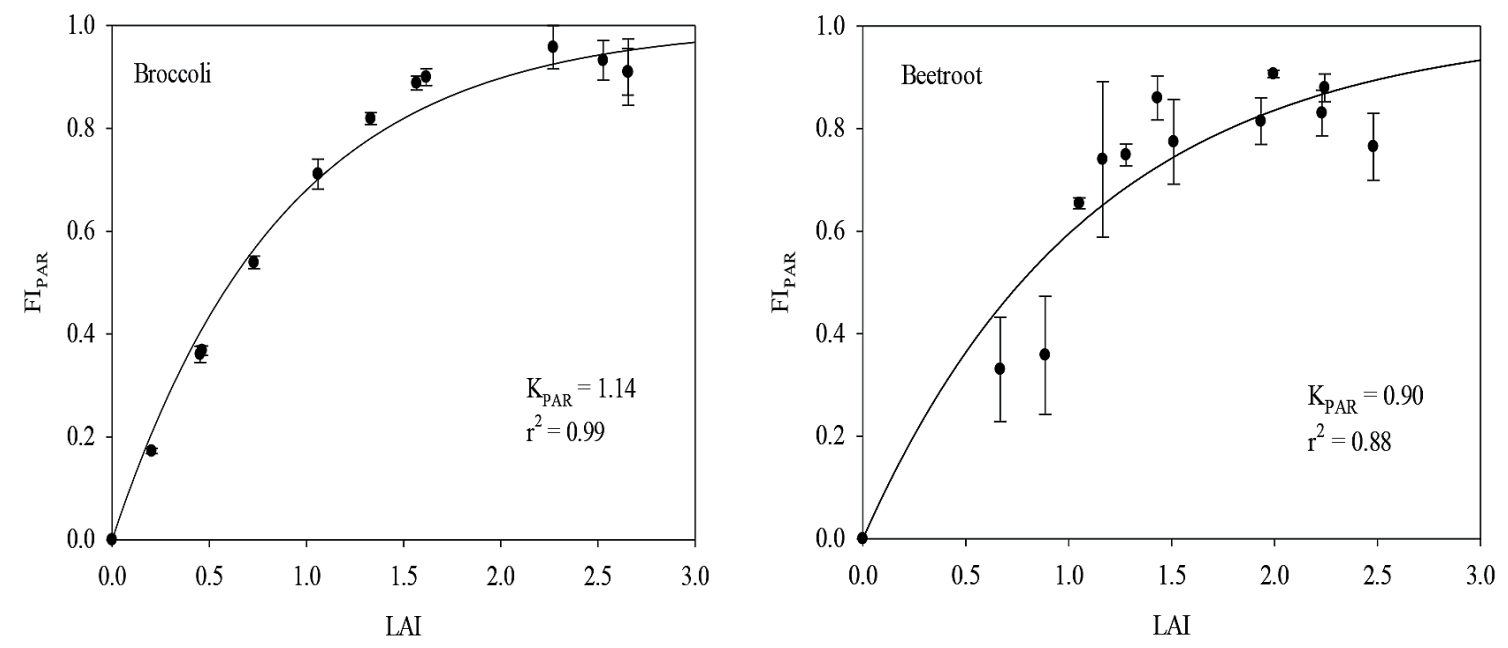

Figure 1

Exponential relationship between leaf area index $(L A l)$ and fractional interception $\left(F I_{P A R}\right)$ of photosynthetically active radiation. $K_{P A R}$ values are given for broccoli and beetroot (winter 2008) 
term radiation-use efficiency is more correct. $R U E$ is not a conservative parameter (Monteith, 1994), but depends on cultivar, water supply, nutrient status and disease (Monteith, 1994; Carretero et al., 2010; Koester et al., 2014; Teixeira et al., 2014). Demetriades-Shah et al. (1992) cautioned against using a constant $R U E$ value for the entire growing season, but both Arkebauer et al. (1994) and Monteith (1994) argued that RUE is rooted in the fundamental relationship between radiant energy use and the accumulation of plant biomass, and is influenced by plant phenology and environmental factors. Examples of the relationship between total $D M$ and cumulative radiation intercepted by cabbage and carrots, used to parameterise SWB, are presented in Fig. 2.

The RUE value for cabbage is $9.4 \times 10^{-4} \mathrm{~kg} \cdot \mathrm{MJ}^{-1}$ and for carrots $7.0 \times 10^{-4} \mathrm{~kg} \cdot \mathrm{MJ}^{-1}$ (Fig. 2). However, RUE values estimated in this way represent a lower limit for utilization of radiation to produce DM (Jovanovic et al., 1999), as root dry matter is not included in the calculations of DM for cabbage and broccoli (marketable yield is above ground). For carrots and beetroot the harvestable storage organ is below ground and was taken, but feeder roots were not taken into consideration with DM measurements. High $\mathrm{r}^{2}$ values were achieved for all experiments (Table 5). Seasonal variation in RUE was observed for the different vegetables, with highest RUE values estimated for the 2008 winter season (Table 5). This is to be expected, as radiation in the summer months is higher than in winter (Table 2), and therefore less likely to limit production. Winter RUE values estimated for the different vegetables were lower, except for carrots, than those reported by Jovanovic et al. (1999) for winter cultivars (carrots cv. Kuroda, $6.0 \times 10^{-4} \mathrm{~kg} \cdot \mathrm{MJ}^{-1}$; cabbage cv. Grand Slam, $1.3 \times 10^{-3} \mathrm{~kg} \cdot \mathrm{MJ}^{-1}$; beetroot $\mathrm{cv}$. Crimson Globe $\left.1.4 \times 10^{-3} \mathrm{~kg} \cdot \mathrm{MJ}^{-1}\right)$. The values determined in winter are expected to better represent actual RUE for these crops, and were therefore used for the simulations. Since SWB uses the lesser of radiation- or water-limited growth, this approach seems reasonable.
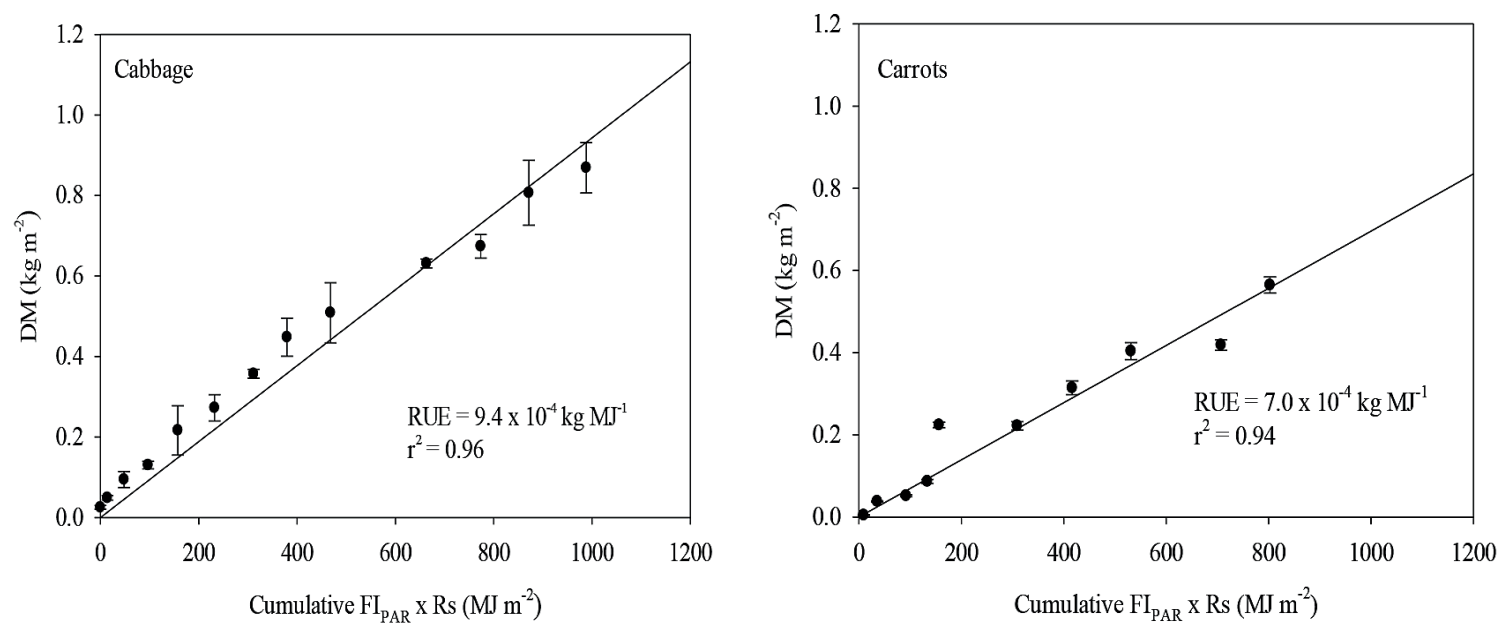

Figure 2

Dry matter (DM) production of cabbage (winter 2008) and carrots (summer 2008), as a function of the cumulative product of fractional interception $\left(F I_{R A D}\right)$ and solar radiation $(R)$. Radiation-use efficiency $(R U E)$ and the coefficient of determination $\left(r^{2}\right)$ are shown
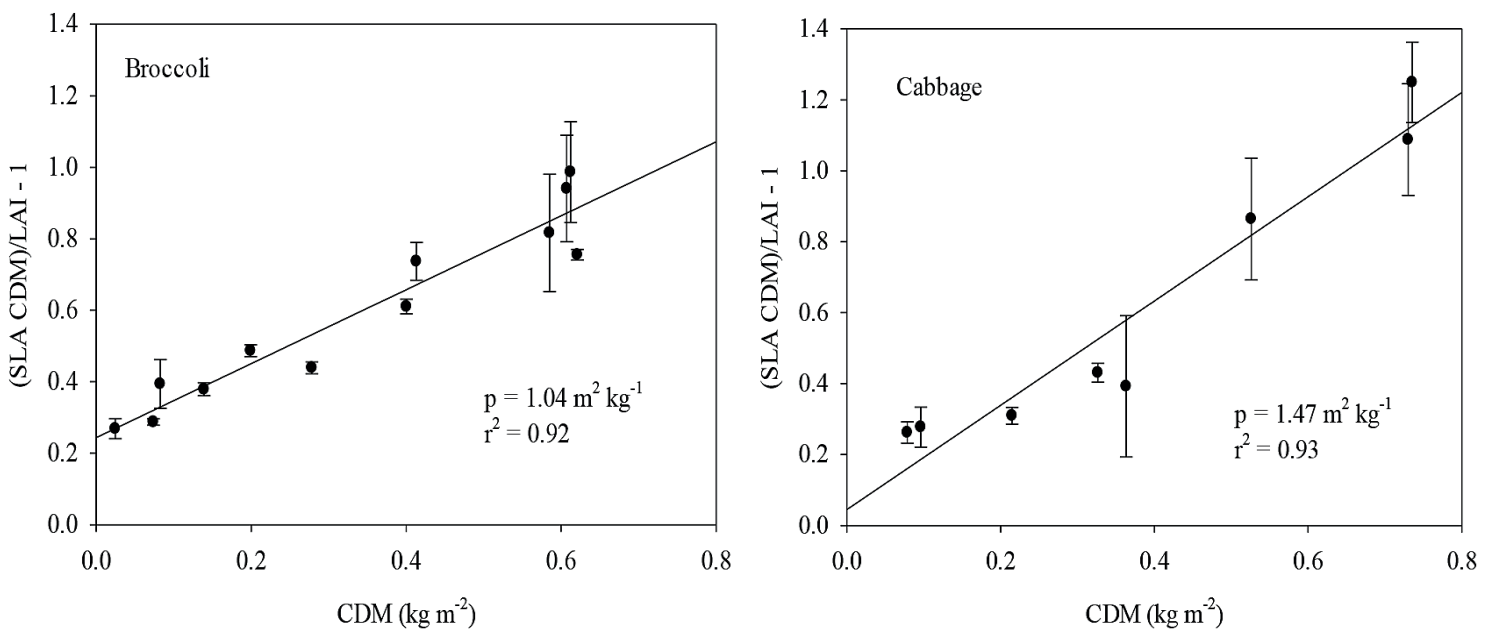

Figure 3

Determination of the leaf-stem dry matter partitioning parameter ( $p$ ) as a function of canopy dry matter (CDM), specific leaf area (SLA) and leaf area index (LAl) for broccoli (winter 2008) and cabbage (summer 2008) 
Examples of the calculation of the leaf stem partition parameter, $p$, for broccoli $\left(1.04 \mathrm{~m}^{2} \cdot \mathrm{kg}^{-1}\right)$ and cabbage $\left(1.47 \mathrm{~m}^{2} \cdot \mathrm{kg}^{-1}\right)$ are given in Fig. 3. The $p$ values for the different crops and seasons are also summarised in Table 5.

Specific leaf area and $p$ (Fig. 3) are used to calculate $D M$ partitioning between leaves and stems with the SWB model. Seasonal variation in $p$ for the different vegetables was observed (Table 5). This is due to cultivar differences for the different seasons and the influence of climate and management practices on plant growth, and therefore the production of CDM and the development of leaf area. In general, high $r^{2}$ values for $p$ were obtained, except for broccoli grown during the 2007/2008 summer season and for carrots grown in the 2008 winter season (Table 5).

The $V P D$-adjusted dry matter water ratios $\left(\mathrm{kg} D M \cdot \mathrm{kg}^{-1}\right.$ water.Pa) determined for the different vegetables and seasons are presented in Fig. 4. Different $D W R$ values for the different cultivars were determined due to different growth and canopy characteristics (Fig. 4). Because ET is adjusted for VPD it was expected that $D W R$ would be reasonably conservative for the same cultivar in different seasons. However, some seasonal variation was evident for beetroot and cabbage (Fig. 4). This variation is probably due to the over-simplification of predicting $D M$ production (eq. 3) and that other factors are not taken into account that may influence photosynthetic rates, such as the leaf nitrogen (N) content (Yamori et al., 2011), and the effect of temperature on respiration rates.

Separate model parameters for the SWB model were determined and adjusted, within acceptable plant physiological limits, to best simulate crop growth and soil water deficits for each crop and growth season of this study. Field measurements of the other growth seasons were then used as independent datasets for the different vegetable species, to validate the different sets of SWB model parameters. A set of parameters were then selected for summer and a separate set for winter, for each crop, which best simulated crop growth and soilwater deficits in summer and winter seasons. This was done to accommodate differences in cultivar and growth pattern of the crops for the different seasons. However, for beetroot, where the same cultivar was planted in both summer and winter, a single set of parameters was used for all three seasons. These parameters are summarised in Table 6.
In Fig. 5, an example of a SWB model calibration simulation of $D M$ and $H D M$ production (solid and broken lines), $L A I$ and soil-water deficits for beetroot is given.

A good correlation was observed between predicted and actual measurements for both $D M$ and $H D M$ production (Fig. 5A) as well as $L A I$ (Fig. 5B). Soil water deficits were also successfully predicted with the model (Fig. 5C) and were therefore used to simulate soil water deficits for the 2007/08 summer (Fig. 6A) and 2008 summer (Fig. 6B) seasons to validate the reliability of the model.

Although the two summer seasons had different rainfall patterns, with the summer of 2007/08 receiving more rainfall than in the 2008 season (Table 4), the soil water deficits were predicted reasonably well by SWB for both seasons (Fig. 6). Crop growth parameters developed for the 2008 summer season were then used in the simulation of cabbage growth and soil water deficits for the 2007/08 summer season. For broccoli and carrots, calibration statistics are given for a summer and winter season. Table 7 presents a summary of the statistical

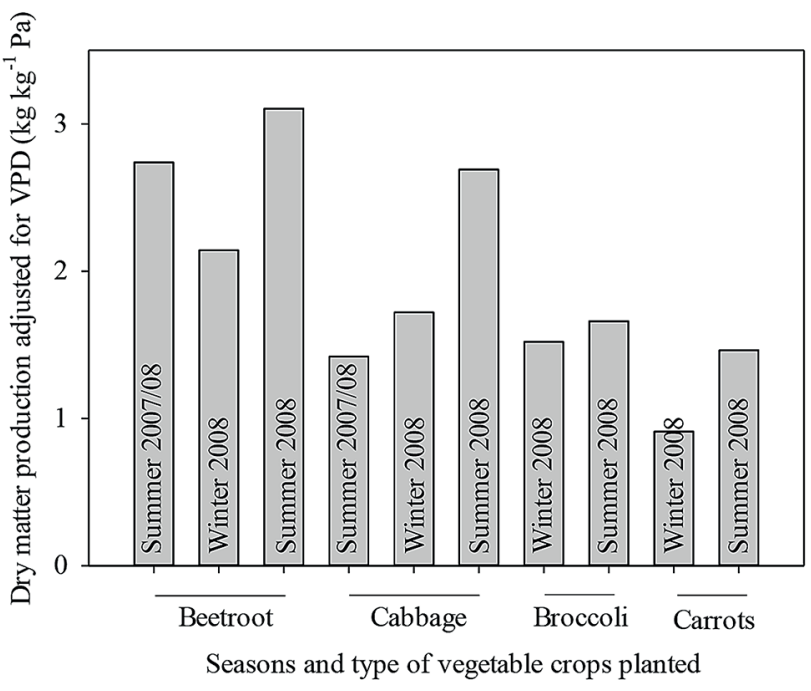

Figure 4

Dry matter production $\left(\mathrm{kg}^{\mathrm{kg}} \mathrm{kg}^{-1}\right)$ adjusted for vapour pressure deficit (Pa) for the different seasons

\begin{tabular}{|c|c|c|c|c|c|c|c|c|}
\hline \multicolumn{9}{|c|}{$\begin{array}{c}\text { TABLE } 5 \\
\text { Measured crop growth parameters for vegetable crops in three different seasons }\end{array}$} \\
\hline Season & Crop & Cultivar & $\mathrm{K}_{\mathrm{PAR}}$ & $r^{2}$ & $\begin{array}{c}\text { RUE } \\
\left(\mathrm{kg} \cdot \mathrm{MJ}^{-1}\right)\end{array}$ & $r^{2}$ & $\begin{array}{c}p \\
\left(m^{2} \cdot \mathrm{kg}^{-1}\right)\end{array}$ & $r^{2}$ \\
\hline \multirow{3}{*}{$\begin{array}{l}\text { Summer } \\
2007 / 2008\end{array}$} & Cabbage & Tenacity & 1.08 & 0.98 & $6.6 \times 10^{-4}$ & 0.93 & 1.29 & 0.93 \\
\hline & Broccoli & Star 2204 & 1.09 & 0.94 & $6.6 \times 10^{-4}$ & 0.96 & 0.30 & 0.07 \\
\hline & Beetroot & Red Ace & 1.11 & 0.96 & $1.1 \times 10^{-4}$ & 0.69 & 0.74 & 0.70 \\
\hline \multirow{4}{*}{$\begin{array}{l}\text { Winter } \\
2008\end{array}$} & Cabbage & Grandslam & 0.87 & 0.98 & $9.4 \times 10^{-4}$ & 0.96 & 0.60 & 0.85 \\
\hline & Broccoli & Parthenon & 1.14 & 0.98 & $9.9 \times 10^{-4}$ & 0.90 & 1.04 & 0.92 \\
\hline & Beetroot & Red Ace & 0.90 & 0.88 & $1.2 \times 10^{-3}$ & 0.78 & 0.58 & 0.81 \\
\hline & Carrots & Dordogne & 0.97 & 0.95 & $8.7 \times 10^{-4}$ & 0.95 & 1.10 & 0.36 \\
\hline \multirow{3}{*}{$\begin{array}{l}\text { Summer } \\
2008 / 2009\end{array}$} & Cabbage & Tenacity & 1.11 & 0.59 & $7.6 \times 10^{-4}$ & 0.96 & 1.47 & 0.93 \\
\hline & Beetroot & Red Ace & 0.95 & 0.97 & $7.5 \times 10^{-4}$ & 0.63 & 2.01 & 0.75 \\
\hline & Carrots & Star 3006 & 1.03 & 0.59 & $7.0 \times 10^{-4}$ & 0.94 & 2.24 & 0.83 \\
\hline
\end{tabular}

$\mathrm{K}_{P A R}:$ Canopy extinction coefficient for photosynthetically active radiation, RUE: Radiation-use efficiency, $\mathrm{p}$ : Leaf-stem dry matter partitioning parameter. 
TABLE 6

Specific crop growth parameters used in the SWB model to simulate crop growth and the soil water balance over 3 seasons

\begin{tabular}{|c|c|c|c|c|c|c|c|c|c|}
\hline \multirow[b]{2}{*}{ Parameter } & \multirow[b]{2}{*}{ Abbreviation } & \multirow[b]{2}{*}{ Units } & \multicolumn{2}{|c|}{ Cabbage } & \multicolumn{2}{|c|}{ Broccoli } & \multirow{2}{*}{$\begin{array}{c}\text { Beetroot } \\
\begin{array}{c}\text { Summer } \\
\text { and } \\
\text { winter }\end{array}\end{array}$} & \multicolumn{2}{|c|}{ Carrot } \\
\hline & & & Winter & Summer & Winter & Summer & & Winter & Summer \\
\hline $\mathrm{DM} / \mathrm{ET}$ ratio corrected for VPD & DWR & $\mathrm{kg} \cdot \mathrm{kg}^{-1} \cdot \mathrm{Pa}$ & 6.0 & 9.0 & 7.0 & 6.0 & 7.0 & 8.0 & 7.0 \\
\hline Radiation-use efficiency & RUE & $\mathrm{gvMJ}^{-1}$ & 0.94 & 0.94 & 1.00 & 1.00 & 1.25 & 0.95 & 0.70 \\
\hline Specific leaf area & SLA & $\mathrm{m}^{2} \cdot \mathrm{kg}^{-1}$ & 9.5 & 12.0 & 9.0 & 10.5 & 12.0 & 11.5 & 16.0 \\
\hline Stem-leaf partitioning parameter & $\mathrm{p}$ & $\mathrm{m}^{2} \cdot \mathrm{kg}^{-1}$ & 0.56 & 1.55 & 1.54 & 1.54 & 3.02 & 3.08 & 2.24 \\
\hline Canopy extinction coeff. for PAR & $K_{\mathrm{PAR}}$ & & 0.87 & 1.11 & 1.09 & 1.14 & 0.90 & 0.97 & 1.03 \\
\hline $\begin{array}{l}\text { Canopy extinction coeff. for total } \\
\text { solar radiation }\end{array}$ & Ks & & 0.62 & 0.78 & 0.81 & 0.77 & 0.64 & 0.69 & 0.70 \\
\hline Max rooting depth & $R D_{\max }$ & $\mathrm{m}$ & 0.60 & 0.60 & 0.60 & 0.60 & 0.60 & 0.60 & 0.60 \\
\hline Base temp. & $\mathrm{Tb}$ & ${ }^{\circ} \mathrm{C}$ & 2.0 & 4.4 & 0.0 & 0.0 & 4.4 & 4.4 & 7.2 \\
\hline Optimum temp. & Topt & ${ }^{\circ} \mathrm{C}$ & 23.9 & 23.9 & 23.9 & 23.9 & 23.9 & 23.9 & 23.9 \\
\hline Day degrees for emergence & emdd & ${ }^{\circ} \mathrm{C}$ & 50 & 130 & 95 & 123 & 64 & 95 & 105 \\
\hline Day degrees until harvest & mtdd & ${ }^{\circ} \mathrm{C}$ & 1445 & 1477 & 1288 & 1899 & 1356 & 1286 & 1281 \\
\hline
\end{tabular}

Notes: $\mathrm{K}_{s}$ and not $\mathrm{K}_{P_{A R}}$ is used in SWB. Cardinal temperatures for cabbage, beetroot and carrots from Maynard and Hochmuth (2007) and broccoli from Tan et al. (2000).
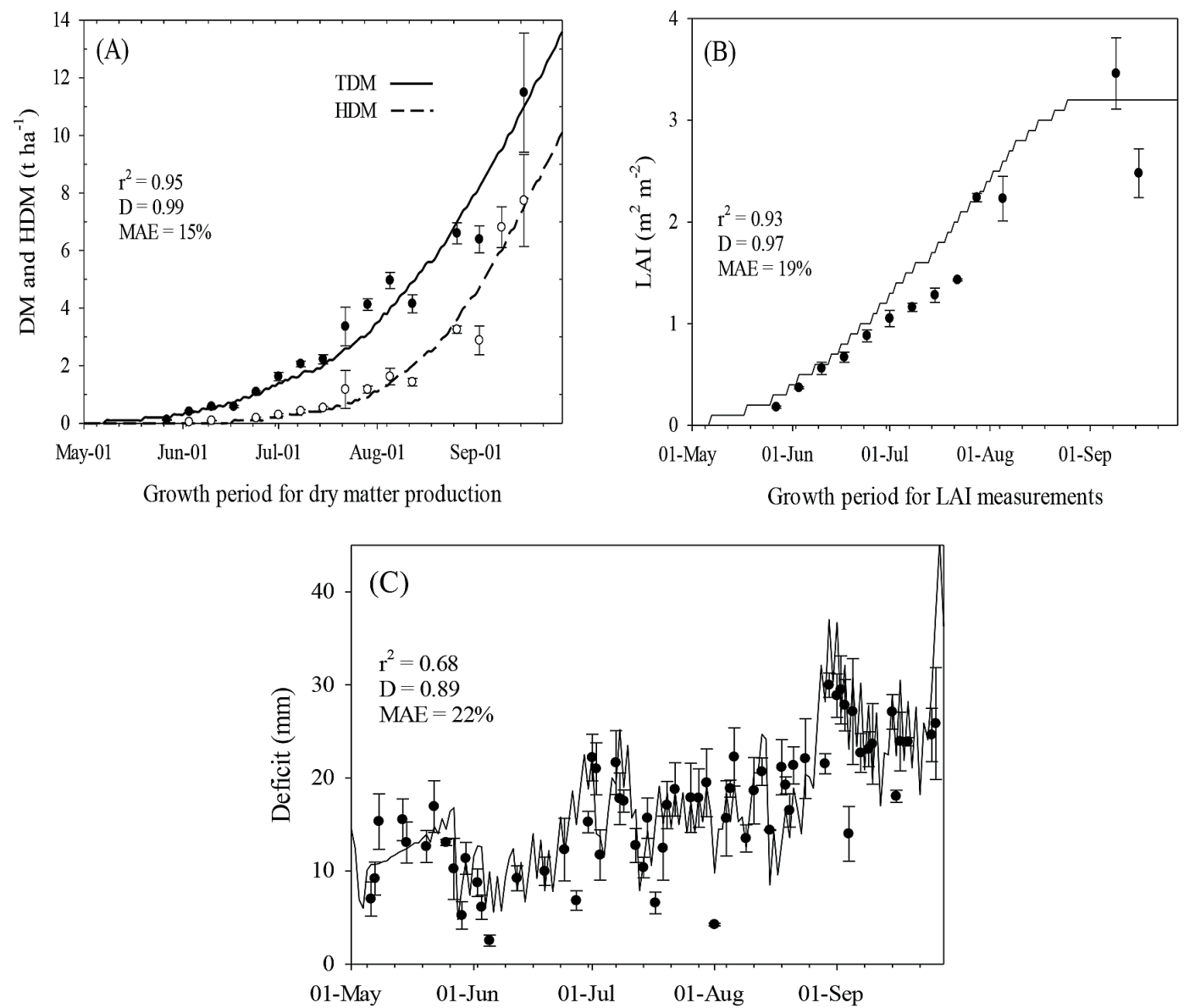

Growth period for modelling soil water deficit

Figure 5

(A) Simulation (solid and broken lines) and actual measurements for dry matter (DM •) and harvestable dry matter production (HDM ०), (B) Simulation (solid line) of leaf area index (LAI) with actual measurements $(\bullet)$ and (C) simulation (solid line) of soil water deficits with actual measurements $(\bullet)$ for beetroot for the 2008 winter season 
analyses for SWB model simulations of soil-water deficits, $D M, H D M$ and $L A I$ for the different seasons. $N$ represents the number of observations, $r^{2}$ is the coefficient of determination and $D$ is Willmott's index of agreement. MAE is the mean absolute error, and is a measure of average differences between observed and predicted continuous variables, and describes average model-performance error (Willmott et al., 2012), which gives an indication of accuracy over time.

High $r^{2}$ and $D$ and low MAE values for the simulation of soil water deficits, DM, HDM and $L A I$ for the calibration seasons indicate that the SWB model was successfully calibrated for the different vegetable crops for summer and winter seasons (Table 7). However, it was found that parameters developed for a specific cultivar performed poorly in simulating crop growth and soil water deficits of another cultivar (data not shown), due to differences in growth characteristics between cultivars. The parameters chosen (winter 2008) for parametrising SWB for beetroot performed reasonably well in predicting crop growth $(D M, H D M$ and $L A I$ ) and soil water deficits for the other two summer seasons. Although the soil water deficits of cabbage were adequately predicted by SWB for the 2007/08 summer season, the model predicted more rapid growth than was observed, which resulted in high MAE for the simulation of DM, HDM and LAI. The SWB model accounts for radiation or water-limited growth, but does not predict disease or nutrient-limited growth. It is possible that due to the high rainfall at the beginning of the 2007/08 season (Table 4), $\mathrm{N}$ leaching from the root zone occurred, which caused $\mathrm{N}$ deficiencies during early development of the cabbage, that increased the growth
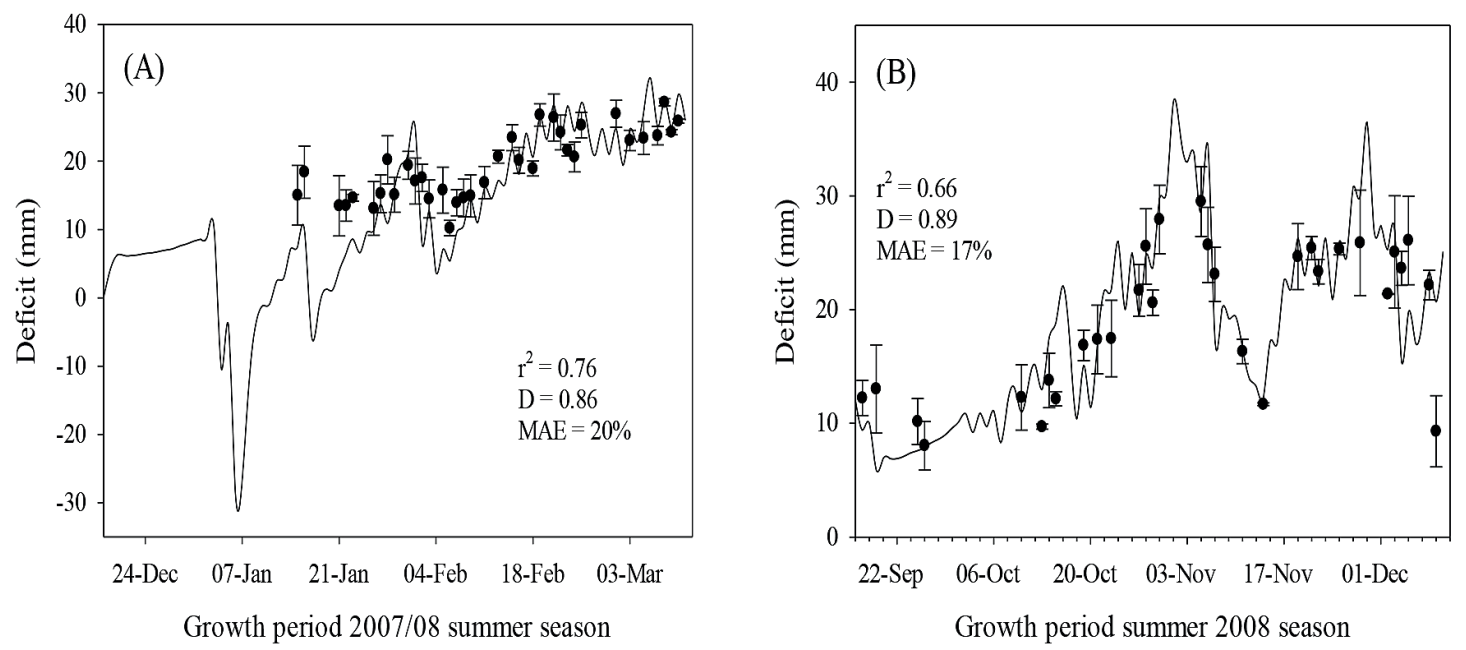

Figure 6

Comparison between SWB validation simulations and field measurements for beetroot in the 2007/08 summer season (A) and 2008 summer season (B)

\begin{tabular}{|c|c|c|c|c|c|c|c|c|c|c|c|c|c|c|}
\hline \multicolumn{15}{|c|}{$\begin{array}{c}\text { TABLE } 7 \\
\text { Statistical analyses of the simulation of soil-water deficits, DM production, and LAI for the different vegetable } \\
\text { crops over three seasons }\end{array}$} \\
\hline \multirow[b]{2}{*}{ Crop } & \multirow[b]{2}{*}{ Cultivar } & \multirow[b]{2}{*}{ Season } & \multicolumn{4}{|c|}{ Soil water deficit } & \multicolumn{4}{|c|}{ Dry matter production } & \multicolumn{4}{|c|}{ Leaf area index } \\
\hline & & & $N$ & $r^{2}$ & $D$ & $\begin{array}{c}\text { MAE } \\
(\%)\end{array}$ & $N$ & $r^{2}$ & $D$ & $\begin{array}{c}\text { MAE } \\
(\%)\end{array}$ & $N$ & $r^{2}$ & $D$ & $\begin{array}{c}\text { MAE } \\
(\%)\end{array}$ \\
\hline \multirow[t]{3}{*}{ Cabbage } & Tenacity & $\begin{array}{l}\text { Summer } \\
\text { 2007/'08 }\end{array}$ & 41 & 0.74 & 0.89 & 26 & 6 & 0.93 & 0.83 & 87 & 7 & 0.68 & 0.83 & 55 \\
\hline & $\begin{array}{l}\text { Grand } \\
\text { Slam }\end{array}$ & *Winter 2008 & 54 & 0.43 & 0.79 & 22 & 14 & 0.96 & 0.97 & 18 & 13 & 0.96 & 0.99 & 9 \\
\hline & Tenacity & ${ }^{\star}$ Summer 2008 & 35 & 0.48 & 0.82 & 22 & 10 & 0.98 & 0.99 & 9 & 10 & 0.91 & 0.96 & 24 \\
\hline \multirow[t]{2}{*}{ Broccoli } & Star 2204 & $\begin{array}{l}\text { *Summer } \\
\text { 2007/'08 }\end{array}$ & 36 & 0.66 & 0.85 & 22 & 7 & 0.98 & 0.99 & 11 & 7 & 0.93 & 0.98 & 19 \\
\hline & Parthenon & *Winter 2008 & 44 & 0.55 & 0.85 & 17 & 12 & 0.92 & 0.97 & 17 & 12 & 0.93 & 0.97 & 16 \\
\hline \multirow[t]{3}{*}{ Beetroot } & Red Ace & $\begin{array}{l}\text { Summer } \\
2007 / \text { '08 }\end{array}$ & 36 & 0.76 & 0.86 & 20 & 4 & 0.98 & 0.93 & 22 & 7 & 0.85 & 0.95 & 16 \\
\hline & Red Ace & ${ }^{*}$ Winter 2008 & 63 & 0.68 & 0.89 & 22 & 15 & 0.95 & 0.99 & 15 & 13 & 0.93 & 0.97 & 19 \\
\hline & Red Ace & Summer 2008 & 35 & 0.61 & 0.87 & 19 & 9 & 0.95 & 0.97 & 24 & 10 & 0.78 & 0.91 & 17 \\
\hline \multirow[t]{2}{*}{ Carrots } & Dordogne & ${ }^{*}$ Winter 2008 & 59 & 0.49 & 0.76 & 27 & 14 & 0.96 & 0.97 & 18 & 13 & 0.96 & 0.99 & 9 \\
\hline & Star 3006 & ${ }^{*}$ Summer 2008 & 37 & 0.62 & 0.84 & 25 & 10 & 0.98 & 0.99 & 9 & 10 & 0.91 & 0.96 & 24 \\
\hline
\end{tabular}

${ }^{*}$ Parameters from these seasons (Calibration season) were used to parameterise the SWB model 
period with 11 days (Table 1). Cabbage development and growth is sensitive to $\mathrm{N}$ deficiencies and Dewi et al. (2010) found that low $\mathrm{N}$ supply can delay cabbage maturity for between 5 and 13 days. This effect was more prominent for early cultivars.

\section{CONCLUSIONS}

Despite being much cooler, more irrigation water was applied during winter than in the summer seasons due to less rainfall to supplement irrigation and a longer growing period, with beetroot having the highest $W P_{F M}$ and broccoli the lowest. The harvest index $\left(H I_{D M}\right)$ was greater for the root crops than for cabbage and broccoli. Crop-specific growth parameters were determined for beetroot, broccoli, cabbage and carrots. Ideally, all cultivars considered in this study should have been grown for two seasons so that independent data would be available for model validation. However, this was only possible for beetroot (cultivar Red Ace) and cabbage (cultivar Tenacity). Parameters for these cultivars are therefore reported with more confidence than for other crops. However, valuable growth analyses and initial model parameter estimates for the other cultivars will be of use to those interested in modelling growth of these crops. The values determined for the RUE parameters are conservative and a seasonal variation was observed with the highest $R U E$ determined for the winter season. $K_{P A R}$ values determined for carrots, cabbage and beetroot were lower for winter than for summer seasons, but this was not true for broccoli. $D W R$ values determined for the different vegetables are conservative and need to be adjusted upwards for parametrisation of the SWB model. Seasonal variation of the partitioning parameter $(p)$ was unique for different cultivars. Therefore, due to differences in growth characteristics between cultivars, separate model parameters for the different cultivars were needed to parametrise SWB. In seasons where the same cultivar was planted, a single set of parameters enabled the successful simulation of growth and soil-water deficits. However, it is important that crop growth models do not oversimplify prediction of $D M$ production for vegetable crops, but should emulate crop growth characteristics to successfully predict crop growth and water use, especially for vegetables with wide ranges and constant development- of new cultivars. These results expand our current dataset of crop growth parameters for vegetables that can be used in a wide range of mechanistic simulation models to improve water management at field and catchment scales.

\section{ACKNOWLEDGEMENTS}

The authors express their gratitude to Mr R Venema of Rosaly Boerdery, who was responsible for crop management and who made his farm available for the trials. This research formed part of a solicited project, WRC K5/1482/4 (Standards and guidelines for improved efficiency of irrigation water use from dam wall release to root zone application) funded and managed by the South African Water Research Commission.

\section{REFERENCES}

ANNANDALE J, JOVANOVIC N, CAMPBELL G, DU SAUTOY N and LOBIT P (2004) Two-dimensional solar radiation interception model for hedgerow fruit trees. Agric. For. Meteorol. 121 (3) 207-225. https://doi.org/10.1016/j.agrformet.2003.08.004 ANNANDALE JG, BENADE N, JOVANOVIC NZ, STEYN JM and
DU SAUTOY N (1999) Facilitating irrigation scheduling by means of the soil water balance model. WRC Report No. 753/1/99. Water Research Commission, Pretoria.

ANNANDALE JG, STIRZAKER RJ, SINGELS A, VAN DER LAAN $M$ and LAKER MC (2011) Irrigation scheduling research: South African experiences and future prospects. Water SA 37 (5) 751-763. https://doi.org/10.4314/wsa.v37i5.12

ARKEBAUER TJ, WEISS A, SINCLAIR TR and BLUM A (1994) In defense of radiation use efficiency: A response to DemetriadesShah et al. (1992). Agric. For. Meteorol. 68 221-227. https://doi.org/ 10.1016/0168-1923(94)90038-8

BACKEBERG GR, BEMBRIDGE TJ, GROENEWALD JA, HAMMES PS, PULLEN RA and THOMPSON H (1996) Policy proposal for irrigated agriculture in South Africa. KV96/96. Water Research Commission, Pretoria.

BELETSE YG, ANNANDALE JG, STEYN JM, HALL I and AKEN ME (2008) Can crops be irrigated with sodium bicarbonate rich CBM deep aquifer water? Theoretical and field evaluation. Ecol. Eng. 33 (1) 26-36. https://doi.org/10.1016/j.ecoleng.2007.12.011

BOOTE KJ, JONES JW, HOOGENBOOM G and WHITE JW (2010) The role of crop systems simulation in agriculture and environment. Int. J. Agric. Environ. Inf. Syst. 1 (1) 41-54. https://doi. org/10.4018/jaeis.2010101303

CAMPBELL GS and NORMAN JM (1998) An Introduction to Environmental Biophysics. Springer, New York.

CAMPBELL GS and VAN EVERT FK (1994) Light interception by plant canopies: Efficiency and architecture. In: Monteith JL, RK Scott and MH Unsworths (eds) Resource Capture by Crops. Nottingham University Press, London.

CARRETERO R, SERRAGO RA, BANCAL MO, PERELLÓ AE and MIRALLES DJ (2010) Absorbed radiation and radiation use efficiency as affected by foliar diseases in relation to their vertical position into the canopy in wheat. Field Crops Res. 116 (1-2) 184-195. https://doi.org/10.1016/j.fcr.2009.12.009

DEMETRIADES-SHAH TH, FUCHS M, KANEMASU ET and FLITCROFT I (1992) A note of caution concerning the relationship between cumulated intercepted solar radiation and crop growth. Agric. For. Meteorol. 58 193-207. https://doi.org/10.1016/0168-192 3(92) $90061-8$

DEWI ER, NIKUS O and HORST WJ (2010) Genotypic differences in nitrogen efficiency of white cabbage (Brassica oleracea L.). Plant Soil 328 (1-2) 313-325.

DU SAUTOY N, JOVANOVIC NZ and ANNANDALE JG (2003) Water balance simulation of a peach orcahrd using the SWB model. S. Afr. J. Plant Soil 20 (4) 6. https://doi.org/10.1080/02571862.2003.10634930

FAO (2017) FAOStat - Food and Agriculture Organization of the United Nations, Statistics Division. URL: http://faostat3.fao.org/ home (Accessed 20 September 2017).

FESSEHAZION MK, ANNANDALE JG, EVERSON CS, STIRZAKER RJ and TESFAMARIAM EH (2014) Evaluating of soil water balance (SWB-Sci) model for water and nitrogen interactions in pasture: Example using annual ryegrass. Agric. Water Manage. 146 (0) 238-248. https://doi.org/10.1016/j.agwat.2014.08.018

GOUDRIAAN J and VAN LAAR H (2012) Modelling Potential Crop Growth Processes: Textbook with Exercises. Springer Science \& Business Media, Dordrecht

JONES HG (2013) Plants and Microclimate: A Quantitative Approach to Environmental Plant Physiology. Cambridge University Press, New York https://doi.org/10.1017/CBO9780511845727

JOVANOVIC NZ and ANNANDALE JG (1999) An FAO type crop factor modification to SWB for inclusion of crops with limited data: Examples for vegetable crops. Water SA 25 (2) 8.

JOVANOVIC NZ and ANNANDALE JG (2000) Crop growth model parameters of 19 summer vegetable cultivars for use in mechanistic irrigation scheduling models. Water SA 26 (1) 67-76.

JOVANOVIC NZ, ANNANDALE JG and MHLAULI NC (1999) Field water balance and SWB parameter determination of six winter vegetable species. Water SA 25 (2) 191-196.

JOVANOVIC NZ, ANNANDALE JG and NEL AA (2000) Calibration and validation of the SWB model for sunflower (Helianthus annuus L.). S. Afr. J. Plant Soil 17 (3) 6.

KOESTER RP, SKONECZKA JA, CARY TR, DIERS BW and AINSWORTH EA (2014) Historical gains in soybean (Glycine max 
Merr.) seed yield are driven by linear increases in light interception, energy conversion, and partitioning efficiencies. J. Exp. Bot. 65 (12) 3311-3321. https://doi.org/10.1093/jxb/eru187

MAYNARD NM and HOCHMUTH GJ (2007) Knott's Handbook for Vegetable Growers. John Wiley and Sons, New Jersey.

MONTEITH JL (1994) Validity of the correlation between intercepted radiation and biomass. Agric. For. Meteorol. 68 213-220. https:// doi.org/10.1016/0168-1923(94)90037-X

PEREIRA LS, ALLEN RG, SMITH M and RAES D (2015) Crop evapotranspiration estimation with FAO56: Past and future. Agric. Water Manage. 147 4-20. https://doi.org/10.1016/j. agwat.2014.07.031

RANATUNGA K, NATION ER and BARRATT DG (2008) Review of soil water models and their applications in Australia. Environ. Model. Softw. 23 1182-1206. https://doi.org/10.1016/j. envsoft.2008.02.003

REINDERS FB and LOUW AA (1984) Infiltration: measurement and use. Department of Agricultural Technical Services, Pretoria.

REINDERS FB, VAN DER STOEP I, LECLER NI, GREAVES KR, VAHRMEIJER JT, BENADÉ N, DU PLESSIS FJ, VAN HEERDEN PS, STEYN JM, GROVÉ B, JUMMAN A and ASCOUGH G (2010) Standards and guidelines for improved efficiency of irrigation water use from dam wall release to root zone application. WRC Report No. 465/10. Water Research Commission, Pretoria.

RITCHIE JT (1972) Model for predicting evaporation from a row crop with incomplete cover. Water Resour. Res. 8 1204-1213. https://doi. org/10.1029/WR008i005p01204

SINCLAIR TR and MUCHOW RC (1999) Radiation use efficiency. in Sparks DLs (ed.) Advances in Agronomy. Academic Press, New York.

SINGELS A, ANNANDALE JG, DE JAGER JM, SCHULZE RE, INMAN-BAMBER NG, DURAND W, VAN RENSBURG LD, VAN HEERDEN PS, CROSBY CT, GREEN GC and STEYN JM (2010) Modelling crop growth and crop water relations in South Africa: Past achievements and lessons for the future. S. Afr. J. Plant Soil 27 (1) 49-65. https://doi.org/10.1080/02571862.2010.10639970

SOIL CLASSIFICATION WORKING GROUP (1991) Soil
Classification. A Taxonomic System for South Africa. Department of Agricultural Development, Pretoria.

STEDUTO P, HSIAO TC, RAES D and FERERES E (2009) AquaCrop-The FAO crop model to simulate yield response to water: Concepts and underlying principles. Agron. J. 101 (3) 426-437. https://doi.org/10.2134/agronj2008.0139s

STÖCKLE CO, KEMANIAN AR, NELSON RL, ADAM JC, SOMMER $\mathrm{R}$ and CARLSON B (2014) CropSyst model evolution: From field to regional to global scales and from research to decision support systems. Environ. Model. Softw. 62 361-369. https://doi. org/10.1016/j.envsoft.2014.09.006

TAN DKY, BIRCH CJ, WEARING AH and RICKERT KG (2000) Predicting broccoli devleopment I. Develoment is predominantly determined by temperature rather than photoperiod. Sci. Hort. 84 227-243. https://doi.org/10.1016/S0304-4238(99)00139-9

TEIXEIRA EI, GEORGE M, HERREMAN T, BROWN H, FLETCHER A, CHAKWIZIRA E, DE RUITER J, MALEY S and NOBLE A (2014) The impact of water and nitrogen limitation on maize biomass and resource-use efficiencies for radiation, water and nitrogen. Field Crops Res. 168 109-118. https://doi.org/10.1016/j. fcr.2014.08.002

TESFAMARIAM EH, ANNANDALE JG, STEYN JM, STIRZAKER RJ and MBAKWE I (2015) Use of the SWB-Sci model for nitrogen management in sludge-amended land. Agric. Water Manage. 152 (0) 262-276. https://doi.org/10.1016/j.agwat.2015.01.023

VAN HALSEMA GE and VINCENT L (2012) Efficiency and productivity terms for water management: A matter of contextual relativism versus general absolutism. Agric. Water Manage. 108 9-15. https://doi.org/10.1016/j.agwat.2011.05.016

WILLMOTT CJ, ROBESON SM and MATSUURA K (2012) A refined index of model performance. Int. J. Climatol. 32 (13) 2088-2094. https://doi.org/10.1002/joc.2419

YAMORI W, NAGAI T and MAKINO A (2011) The rate-limiting step for $\mathrm{CO}_{2}$ assimilation at different temperatures is influenced by the leaf nitrogen content in several C3 crop species. Plant Cell Environ. 34 (5) 764-777. https://doi.org/10.1111/j.1365-3040.2011.02280.x 